\title{
Visual capabilities and its impact on the performance of basketball skills methodological For students for the second stage of Basic Education *Dr/ Walid Ibrahim Ahmed Abstract of search:
}

Visual capabilities are a key partner in all sports activities that generally require a wide variety of motor communication and visual abilities. The aim of the research is to identify the impact of visual capabilities on the performance of basketball skills methodological For students for the second stageof the Basic Education, The researcher used the experimental approach to suit the nature of the research using the experimental design of one group with the tribal and the barricade measurements. The research community represents the second cycle students in the second stage of secondary education in Assiut city, 334 students who study basketball within the curriculum during the 2013/2014 academic year, The sample of the study was randomly selected by the second grade of the preparatory school. The sample was 30 students with $11.1 \%$ of the total research society, The most important conclusions (visual abilities under study have a positive impact on the level of performance of the following basic methodological skills, Visual capabilities led to the improvement of the experimental group in the technical Visual capabilities, the correlative relationship between some Visual capabilities and the basic methodological skills of basketball students of the second cycle of basic education.

\section{Key words : Visual capabilities - Methodological skills Basketball:}

\section{Introduction:}

The visual capacity is a key partner in all activities conducted Riyadh Yeh Which generally require a system wide variety of communication and kinetic visual capabilities.
He adds , "Brin aryl Brain Ariel "(2004) that the visual capabilities a branch barometric (considering measurements), a branch is interested in considering

* Associate professor in Department of Curriculum and Teaching of Physical Education, Eaculty of Physical Education, Assiut University, Egypt. Assiut Journal For Sport Science Arts 
cognition and evaluate and improve visual performance in addition to identifying the most appropriate visual tools for the nature of sports activity. (10: 127)

Has been known, "Majid Mustafa Ahmed Ismail, Mohsen Zakaria Ahmed "(2006) Optical capacity Visual skills : Are the variables that can be modified their behavior by influencing vision which is the source of the eye, whether this effect internally or externally. (5: 87)

$\mathrm{He}$ points out "Isabel Walker "(2001) that coaches, teachers, athletes, players and scientists sport permanently and continuously searching for new educational and training methods in order to improve athletic performance and gain a competitive advantage, the visual capacity is considered one of the techniques presented in the sports field. It also adds that the visual capacity is a frequent series of eye exercises in order to improve the visual basic functions, which are important for athletes in all competitive games . (12: 103)

Visual capabilities used in the program:

Visual abilities are common in a wide range of sports and are often associated with a particular sport but sports activities generally require a wide variety of visual abilities. The most important visual abilities used in the program are:

\section{1- Precision optical} animation: Dynamic Visual Acuity:It is also known as the ability of the individual to follow the details in the field of vision when the movement is relative between the player and the goal of the unit of motor vision less important for athletes who do not need to follow moving targets quickly. $(14: 25)$

\section{2- The ability to see things around (outer awareness):} Peripheral vision:Is the ability to see things outside the focus of both sides and up and down, and it is one of the most valuable visual abilities can be owned by the athlete, and the vision beyond the 180 degrees of both sides is an abnormal phenomenon which enables the player to see more play areas, the movement of other players , The ball all at once. (13:21)

\section{3- Optical tracking} capability: Visual tracking skills :It means the individual's ability to keep track of moving targets without much 
movement of the head and is considered sports that use the tool or by the direct contact and face - to - face with rival And that you need to keep track of the eye to help to keep the balance and interaction with the situation more quickly, and the optical tracking needs to certain types of eye movements, including the rapid eye movements, which is short in the eye 's ability to recognize the rival movements.

4. The response capacity of the optical reaction speed: Skills, Visual reaction speed:The visual reaction component is important for performance in dynamic sports that require rapid reaction. It is widely used, but its measurement is complex because what is actually measured is the motor response of an optical stimulus, the speed at which the brain interprets the reaction of the opponent. (1:28)

5- capacity Perception Depth: Depth perception:Appreciation Sound For speed And distance Relativity Required during Performance. (5: 87)

that There are a linked Between perception Depth
With a lot From Activities Sports There Relationship theory between Activities Sports Different Skills Visual They say that Two-thirds the games Sports Depends Depending Great Ali perception It is Factor Important to reach to me summit the performance Where Need Athlete to me Appreciation distance Objectives And that is being Able Ali Action that Quickly at Shadow pressure Competition Dynamic. (28: 26)

\section{Research Problem:}

The diversity of the abilities of individuals and this difference affects the speed of their response and learning despite the convergence of variables surrounding the learners, such as age and content provided, education and the surrounding environment is a large, and this is what researchers call to try new ways and methods and innovative research variables that may have an impact in the learning process, of the factors that may have an impact in improving motor skills performance level, and deficiencies in that capacity is one of the common factors that may lead to learning 
difficulties, where is the eye and capacity related one of the workshops and a T r's between the learner and the world Alkha In the follow-up of the researcher in his academic and professional capacity, he noticed shortcomings in the responses of beginners when learning the skills of basketball and the associated weakness of the ability to determine the direction of the ball and its level and speed and the learners involved with them in performance which may be a cause of confusion of learners and the lack of ability to master the basic skills in the ball Basketball gradient to learn from the acquisition of the initial compatibility of performance skills even advanced stages of performance under the pressure of competition.

Research objectives :

Research aims to identify The impact of Visual capacity to perform basketball skills methodology For students for the second stage of the basic education.

\section{Assumptions research:}

1- There are statistically significant differences between the mean scores of the two measurements pre and post experimental group for post visual capabilities associated with the measurement methodology skills.

2- There are statistically significant differences between the mean scores of the two measurements pre and post experimental group for post measurement methodology skills in basketball performance.

3- There are statistically significant between the visual capabilities and the level of methodological skills for the experimental group 's performance relationship under discussion in basketball.

\section{Search Terms:}

Visual capabilities:

It is: the variables that can be adjusted by influencing the vision of the eye, a source of influence, whether internally or externally. (6: 16)

\section{Methodological \\ skills}

\section{Basketball:}

Are the basic skills Basketball provided in a simplified form of proportional Ot Drasha pupils the second cycle of basic education which is (dribbling _ Chest pass _ shoulder pass _ Set shot _ Layup-shot _ defensive footwork).

\section{Curriculum research:}


use researcher Approach Experimental For his occasion For nature search using the design Experimental Mjmo to an end of Wa Ah B yen measurement Tribal And post.

Society and the research sample:

Represent Community search Pupils of the second cycle of basic education second grade - in Assiut And their number (334), a pupil who Studying football The basket within Curriculum Study During General Study 2013/2014 selected as a sample The study of the way Intentional Random Of second graders from junior university preparatory school where Hit a sample Search (30), a pupil in the rate of $(11.1 \%)$ of Total Community Search market researcher used the (10) students from the same research sample for transacts scientific community and outside of the core sample, And so on To calculate Transactions Scientific (Believe Differentiation) for tests Used at search, And to experiment the program
Education They also hired 10 students as a sample reconnaissance.

\section{Domain Time:}

Done finding Transactions Scientific studies For tests And conduct Measurements :

- Measurements Tribal During Period From 8/2/2014 to 11/2/2014.

- And application the program Education During Period From $3 / 3 / 2014$ to $20 / 4 / 2014$.

- And measurements Dimensionality During Period From 22/4/2014 to 4/23/2014.

Scientific transactions tests visual capabilities and skills tests:

\section{visual capacity tests:}

\section{- Honesty coefficient:}

The researcher has used honestly differentiation in the visual capacity tests under the selection of 10 students from the same research community and outside of the sample core group is distinct and other (10) pupils featured as a group they are students of the school basketball team, where the researcher applying the tests from 13 /2/2014 to $15 / 2 / 2014$

Table (1) 
Indication of differences between the two distinct and noncharacteristic groups in the visual abilities tests under study ( 1 $=\mathbf{N} 2=10$ ).

\begin{tabular}{|c|c|c|c|c|c|c|c|c|}
\hline \multirow[t]{2}{*}{$\mathbf{N}$} & \multirow{2}{*}{\multicolumn{2}{|c|}{$\begin{array}{l}\text { Statement } \\
\text { Variables }\end{array}$}} & \multirow[t]{2}{*}{ Module } & \multicolumn{2}{|c|}{$\begin{array}{l}\text { Indiscriminate } \\
\text { group }(\mathrm{N}=10)\end{array}$} & \multicolumn{2}{|c|}{$\begin{array}{c}\text { Special } \\
\text { group } \\
(\mathbf{N}=\mathbf{1 0}) \\
\end{array}$} & \multirow[t]{2}{*}{$\begin{array}{c}\text { (T) } \\
\text { Value }\end{array}$} \\
\hline & & & & $(\mathrm{N})$ & (SD) & $(\mathrm{N})$ & (SD) & \\
\hline 1 & $\begin{array}{l}\text { Test the sf } \\
\text { visual rec }\end{array}$ & $\begin{array}{l}\text { eed of } \\
\text { tion }\end{array}$ & Number & 8.20 & 2.20 & 10.30 & 1.25 & 2.62 \\
\hline \multirow{2}{*}{2} & \multirow{2}{*}{$\begin{array}{l}\text { Optical } \\
\text { precision } \\
\text { test }\end{array}$} & Right & Degree & 1.20 & 0.79 & 2.10 & 0.57 & 2.93 \\
\hline & & Left & Degree & 1.20 & 0.79 & 2.10 & 0.74 & 2.63 \\
\hline \multirow{2}{*}{3} & \multirow{2}{*}{$\begin{array}{c}\text { External } \\
\text { Awareness } \\
\text { Test }\end{array}$} & Right & Degree & 1.90 & 0.88 & 3.60 & 0.52 & 5.29 \\
\hline & & Left & Degree & 1.80 & 1.03 & 3.40 & 0.70 & 4.06 \\
\hline 4 & \multicolumn{2}{|c|}{ Optical tracking test } & Degree & 1.90 & 0.99 & 3.60 & 0.70 & 4.42 \\
\hline \multirow{5}{*}{5} & \multirow{5}{*}{$\begin{array}{l}\text { Test depth } \\
\text { perception }\end{array}$} & 10 & $\mathrm{~cm}$ & 4.00 & 3.01 & 9.00 & 3.16 & 2.31 \\
\hline & & 15 & $\mathrm{~cm}$ & 6.00 & 5.75 & 13.50 & 4.74 & 2.29 \\
\hline & & 20 & $\mathrm{~cm}$ & 8.00 & 7.23 & 18.00 & 6.32 & 2.14 \\
\hline & & 25 & $\mathrm{~cm}$ & 10.00 & 9.14 & 22.50 & 7.91 & 2.26 \\
\hline & & 30 & $\mathrm{~cm}$ & 12.00 & 11.10 & 27.00 & 9.49 & 2.19 \\
\hline
\end{tabular}

The value of (T) Tabulated at the level of $0.05=2.10$

Seen from the table (12) and no statistically significant differences at the level (0.05) between the distinctive and distinctive groups ranging value of "T" calculated between (2.14: 5.29) and the value of $(\mathrm{t})$ calculated greater than (c) Tabulated suggesting that tests distinguish between individuals, which confirms its sincerity.

- Stability: 
Table (2)

The correlation coefficients between the first application and the second application in the optical capacity tests are under consideration $(\mathrm{N}=10)$

\begin{tabular}{|c|c|c|c|c|c|c|c|c|}
\hline \multirow[t]{2}{*}{$\mathbf{M}$} & \multirow{2}{*}{\multicolumn{2}{|c|}{ variable }} & \multirow[t]{2}{*}{$\begin{array}{c}\text { measurement } \\
\text { unit }\end{array}$} & \multicolumn{2}{|c|}{$\begin{array}{c}\text { first } \\
\text { Execution }\end{array}$} & \multicolumn{2}{|c|}{$\begin{array}{c}\text { second } \\
\text { Execution }\end{array}$} & \multirow[t]{2}{*}{ Correlation } \\
\hline & & & & $(\mathbf{N})$ & (SD) & $(\mathrm{N})$ & (SD) & \\
\hline 1 & \multicolumn{2}{|c|}{$\begin{array}{l}\text { Test the speed of } \\
\text { visual reaction }\end{array}$} & Number & 8.20 & 2.20 & 8.50 & 2.27 & 0.98 \\
\hline \multirow{2}{*}{2} & \multirow{2}{*}{$\begin{array}{l}\text { Optical } \\
\text { precision } \\
\text { test }\end{array}$} & Right & Degree & 1.20 & 0.79 & 1.40 & 0.70 & .85 \\
\hline & & Left & Degree & 1.20 & 0.79 & 1.30 & 0.95 & 0.95 \\
\hline \multirow[b]{2}{*}{3} & \multirow{2}{*}{$\begin{array}{c}\text { External } \\
\text { Awareness } \\
\text { Test } \\
\end{array}$} & Right & Degree & 1.90 & 0.88 & 2.10 & 0.74 & 0.88 \\
\hline & & Left & Degree & 1.80 & 1.03 & 2.00 & 0.82 & 0.92 \\
\hline 4 & \multicolumn{2}{|c|}{$\begin{array}{c}\text { Optical tracking } \\
\text { test }\end{array}$} & Degree & 1.90 & 0.99 & 2.10 & 0.74 & 0.92 \\
\hline \multirow{5}{*}{5} & \multirow{5}{*}{$\begin{array}{c}\text { Depth } \\
\text { perception } \\
\text { test }\end{array}$} & 10 & $\mathrm{~cm}$ & 4.00 & 3.01 & 5.00 & 4.12 & 0.82 \\
\hline & & 15 & $\mathrm{~cm}$ & 6.00 & 5.75 & 7.50 & 6.98 & 0.82 \\
\hline & & 20 & $\mathrm{~cm}$ & 8.00 & 7.23 & 10.00 & 9.15 & 0.82 \\
\hline & & 25 & $\mathrm{~cm}$ & 10.00 & 9.14 & 12.50 & 11.53 & 0.82 \\
\hline & & 30 & $\mathrm{~cm}$ & 12.00 & 11.10 & 15.00 & 14.14 & 0.82 \\
\hline
\end{tabular}

The value of "R" Tabulated at $0.05=0.632$

The correlation coefficient between the first application and the second application D. Statistically at Tests Optical Capabilities Constraint Research which shows the stability of those tests, where the value of the correlation coefficient ranged Between (0.82: 0.98) which is greater than the values at The Tabulated (0:05).

Studies Reconnaissance:

Done studying Exploration at Period 25/2/2014 to 28/2/2014 Measurement Tribal : Done Procedure Execution Measurement Tribal Of variables Constraint search Of the group Control The demo of During Period From $(8 / 2 / 2014$ to $11 / 2 / 2014)$ sample the basic Constraint Search.

1- Measure level the performance Al Mahary For the sample the basic at Skills the basic methodology Constraint search And so on From During the exams Skills Associated with Skills Constraint The search, Attachment No. 5.

2- $\quad$ Measure level Variables Visual And so on From During the exams Visual Constraint 
The search, Attachment number (4).

Execution And application Program: -

Done Execution the program using The amount $t$ Visual To teach Skills the basic Methodology for basketball On Students The second cycle of basic education (Group Demo of).

Telemetric: -

Done

Procedure

Measurements Dimensionality Of variables Constraint search Of the group Demo of a sample search at Period 22/4/201 4 p.m. Even 23/4/201 4 p.m. And the same the conditions Which Done Followers at Measurement Tribal.

\section{Table (3)}

Significance of differences between the averages of two measurements pre and post experimental group in the visual capacity $(\mathrm{N}=30)$

\begin{tabular}{|c|c|c|c|c|c|c|c|c|c|}
\hline \multirow[t]{2}{*}{$\mathbf{M}$} & \multirow{2}{*}{\multicolumn{2}{|c|}{ variable }} & \multirow{2}{*}{$\begin{array}{c}\text { Measure- } \\
\text { ment } \\
\text { unit }\end{array}$} & \multicolumn{2}{|c|}{$\begin{array}{c}\text { Post } \\
\text { measurement }\end{array}$} & \multicolumn{2}{|c|}{$\begin{array}{c}\text { Pre } \\
\text { Measurement }\end{array}$} & \multirow{2}{*}{$\begin{array}{l}\text { Improvement } \\
\text { rate }\end{array}$} & \multirow{2}{*}{$\begin{array}{l}(\mathbf{T}) \\
\text { Value }\end{array}$} \\
\hline & & & & $(\mathbf{N})$ & (SD) & $(\mathbf{N})$ & (SD) & & \\
\hline 1 & \multicolumn{2}{|c|}{$\begin{array}{l}\text { Test the speed of } \\
\text { visual reaction }\end{array}$} & Number & 7.47 & 2.11 & 10.10 & 2.16 & 35.21 & 15.54 \\
\hline \multirow{2}{*}{2} & \multirow{2}{*}{$\begin{array}{l}\text { Optical } \\
\text { precision } \\
\text { test }\end{array}$} & Right & Degree & 1.17 & 0.59 & 2.33 & 0.61 & 99.15 & 16.86 \\
\hline & & Left & Degree & 0.90 & 0.71 & 1.97 & 0.72 & 118.9 & 19.75 \\
\hline \multirow{2}{*}{3} & \multirow{2}{*}{$\begin{array}{c}\text { External } \\
\text { Awareness } \\
\text { Test }\end{array}$} & Right & Degree & 1.77 & 0.86 & 3.73 & 0.83 & 110.7 & 21.98 \\
\hline & & Left & $\mathrm{D}$ & 1.47 & 0.97 & 3.57 & 0.94 & 14 & 21.00 \\
\hline 4 & \multicolumn{2}{|c|}{ Optical tracking test } & Degree & 1.57 & 1.04 & 3.53 & 0.86 & 124.8 & 17.52 \\
\hline \multirow{5}{*}{5} & \multirow{5}{*}{$\begin{array}{l}\text { Test depth } \\
\text { perception }\end{array}$} & 10 & $\mathrm{~cm}$ & 6.00 & 4.98 & 9.67 & 1.83 & 61.17 & 3.61 \\
\hline & & 15 & $\mathrm{~cm}$ & 9.50 & 7.35 & 14.50 & 2.74 & 52.63 & 3.34 \\
\hline & & 20 & $\mathrm{~cm}$ & 12.00 & 9.97 & 19.33 & 3.65 & 61.08 & 3.61 \\
\hline & & 25 & $\mathrm{~cm}$ & 13.33 & 12.69 & 24.17 & 4.56 & 81.32 & 4.71 \\
\hline & & 30 & $\mathrm{~cm}$ & 11.00 & 14.70 & 29.00 & 5.48 & 163.6 & 5.83 \\
\hline
\end{tabular}

The value of (T) Tabulated at the level of $(0.05)=2.31$

Assiut Journal For Sport Science Arts
Methods Statistics Used : -

$\mathrm{He}$ did researcher using the program Statistical analysis Excel to process data Statistically This The Done Approximation Grades to me closer Two digits Decimal places.

Presentation and discussion of the results:

To achieve Goals search And verification From Health Assumptions e Will Reviews researcher Show The results And discussed according to the order of hypotheses as follows:

1- View and discuss the results of the first hypothesis: 
Is evident from the results table (3) There are statistically significant differences between the averages of two measurements pre and post experimental group in capacity Visual Under consideration for the average telemetric where the value of "T" calculated ranged between (3.34: 21.98) and the rate of improvement in its value ranged between (35.21\%: $163.6 \%$ ).

It is clear From Schedule number (3) Special In the group Experimental at The Standards Tribal And beyond Of variables Visual Existence Differences Dale Statistically between The Standards Tribal And beyond Of the group Experimental at the exams Visual At Level (0.05) in favor of Measurement Dimension Where Ranged Values "T" calculated What between (3.34: 21.98) The Hit A Say Its values (T) (3.34) which is What Is represented at Depth perception test, when Hit A Enlarge Its values (T) (21.98), a What Is represented at Exam Awareness of the external eye Right.

It agrees that And results a study "Majid Mostafa Ahmed "," Heb d Enhanced Zakaria
"(2006) (5), Where They pointed out to me effectiveness Use Training Vision Visual at picture a program To train Eye, Where Lead that to me improvement the performance Optical And the skill of the player. Similar to the results of this study with the results of the study "Adel Ahmed Tamim" (2013) (1) The researcher found that the visual training program has proven effective in improving the skills of field hockey. Study "Abrens, Wood Abernethy \& wood "(2004) (8) where the researcher found that the program of visual training has a positive effect in improving the visual capabilities - is also working to improve motor performance in the sport of squash.

And from During What Previously Concludes researcher that Use Walt Marenat Visual within the program LED to me Improvement The capabilities of Visual And this Results Checks Health Imposition the first Which States On: "

$\mathrm{C}$ and $\mathrm{d}$ Differences between Averages

Degrees

Measurement yen Tribal And beyond Of the group Experimental

Favor 
Measurements Dimensionality at Variables Visual "(grasp the depth of vision - Accuracy animated visual - external

Table (4)

awareness - tracking visual visual reaction speed ).

2- View and discuss the results of the second hypothesis:

\section{Significance of differences between the averages of two} measurements pre and post experimental group variables in the skill $(\mathbf{n}=\mathbf{3 0})$

\begin{tabular}{|c|c|c|c|c|c|c|c|c|}
\hline \multirow[t]{2}{*}{$\mathbf{M}$} & \multirow{2}{*}{$\begin{array}{c}\text { Methodological } \\
\text { skills }\end{array}$} & \multirow{2}{*}{$\begin{array}{c}\text { Measure- } \\
\text { ment } \\
\text { unit }\end{array}$} & \multicolumn{2}{|c|}{$\begin{array}{c}\text { Post } \\
\text { measurement }\end{array}$} & \multicolumn{2}{|c|}{$\begin{array}{c}\text { Pre } \\
\text { Measurement } \\
\end{array}$} & \multirow{2}{*}{$\begin{array}{c}\text { Rate of } \\
\text { improvement }\end{array}$} & \multirow{2}{*}{$\begin{array}{c}(\mathrm{T}) \\
\text { Value }\end{array}$} \\
\hline & & & $(\mathbf{N})$ & (SD) & $(\mathbf{N})$ & (SD) & & \\
\hline 1 & $\overline{~ D i a l o g}$ & Degree & 2.30 & 0.79 & 7.63 & 0.61 & 231.7 & 29.38 \\
\hline 2 & Chest pass & Degree & 13.53 & 2.16 & 24.57 & 3.02 & 81.60 & 15.68 \\
\hline 3 & Pitching & Degree & 11.93 & 2.12 & 23.63 & 3.34 & 98.07 & 17.08 \\
\hline 4 & $\begin{array}{c}\text { Peaceful } \\
\text { correction } \\
\end{array}$ & $\begin{array}{c}\text { the } \\
\text { second }\end{array}$ & 46.17 & 1.03 & 42.06 & 3.68 & 9.77 & 6.40 \\
\hline 5 & $\begin{array}{c}\text { Stability } \\
\text { correction } \\
\end{array}$ & Degree & 10.27 & 1.62 & 15.47 & 1.28 & 50.63 & 24.62 \\
\hline 6 & $\begin{array}{c}\text { Foot } \\
\text { movements }\end{array}$ & $\begin{array}{c}\text { the } \\
\text { second }\end{array}$ & 31.53 & 1.60 & 28.70 & 1.51 & 9.86 & 19.61 \\
\hline
\end{tabular}

The value of (T) Tabulated at the level of $(0.05)=2.31$

Is evident from the results table (4) There are statistically differences between the averages of two measurements pre and post experimental group in the variables Skills in question in favor of the average telemetric where the value of "T" calculated ranged between (6.40: 29.38) and the rate of improvement in its value ranged between $(6.74 \%$ : $231.7 \%$ ).

It is clear From Schedule (4) Special In the group Demo at The Standards Tribal And beyond For tests Skills Existence Differences Dale
Statistically between The Standards Tribal And beyond Of the group Experimental at the exams Skills At level (0.05) in favor of Measurement Dimension Where Hit Larger Valuable (T) (29.38), a What Is represented at Exam Skill Interviewing, at when Hit Less Valuable (T) (6.40) which is What Represent Exam Salma correction sent from the right. And $t$ discerned Percentage Improvement between Mediterranean The Standards Tribal And beyond I have the group Experimental between (6.74\%: 231.7\%) It may be This improvement is 
the result of the program Followed gesticulate Include it From Activities And exercises Visual.

\section{Due} researcher Improvement the group Experimental It may be a result of effectiveness the program using Capacity Visual Which Use it researcher at education Skills the basic Methodology for basketball Where A n Put The capabilities of at picture Exercises With the visual mix Palmeara $\mathrm{v}$ basic methodology in the form of educational steps Helps On Success Learn it And so on when In which From suspense And Hamas Desire at show Capacity Kinetics For the student as well as making the share of sports education by attracting students to go to school And why? Include it From Activities And exercises Visual Public or Visual Special.

You see All From "Ceyhan Fouad, Faith Abdallah Zaid
(2005) (3) Eyes Navigate What You see to me Brain Which The By course Organized by the performance at Light Data Which happened on her From Eye And therefore The vision Wrong Dealing with her Brain in a way Reflected On the performance Skill that Ability On Take Decisions And performance Sound Builds On Vision Good.

And this is confirmed Health Imposition The second Which States On: " There are Differences Function Statistically between Averages Degrees The Standards Tribal And beyond of the group Experimental Favor Measurement Dimension at level performance Skills methodology The ball Basketball.

Presentation and discussion of the results of the third hypothesis:

\section{Table (5)}

The relationship between visual abilities and performance of the experimental group's methodological skills In basketball for students of the second cycle of basic education under study $(n=30)$

\begin{tabular}{|c|c|c|c|c|c|c|c|c|}
\hline M & \multicolumn{2}{|c|}{$\begin{array}{r}\text { Methodological } \\
\text { skills } \\
\text { Capabilities } \\
\text { Capal }\end{array}$} & Dribbling & $\begin{array}{l}\text { Chest } \\
\text { pass }\end{array}$ & $\begin{array}{c}\text { shoulder } \\
\text { pass }\end{array}$ & $\begin{array}{l}\text { Set } \\
\text { shot }\end{array}$ & $\begin{array}{l}\text { Lay- } \\
\text { up- } \\
\text { shot }\end{array}$ & $\begin{array}{l}\text { defensive } \\
\text { footwork }\end{array}$ \\
\hline 1 & \multicolumn{2}{|c|}{$\begin{array}{c}\text { Visual reflex } \\
\text { speed }\end{array}$} & $0.89 *$ & $0.98 *$ & $0.96 *$ & $0.52 *$ & $0.97 *$ & $0.94 *$ \\
\hline \multirow{2}{*}{2} & \multirow{2}{*}{$\begin{array}{l}\text { Optical } \\
\text { motion } \\
\text { resolution }\end{array}$} & Right & $0.71 *$ & $0.87 *$ & $0.88 *$ & $0.62 *$ & $0.82 *$ & $0.88 *$ \\
\hline & & Left & $0.75 *$ & $0.91 *$ & $0.90 *$ & $0.49 *$ & $0.92 *$ & $0.89 *$ \\
\hline
\end{tabular}


Follow Table (5)

The relationship between visual abilities and performance of the experimental group's methodological skills In basketball for students of the second cycle of basic education under study $(n=30)$

\begin{tabular}{|c|c|c|c|c|c|c|c|c|}
\hline M & \multicolumn{2}{|c|}{$\begin{array}{r}\text { Methodological } \\
\text { skills } \\
\text { Capabilitios } \\
\text { Capal }\end{array}$} & Dribbling & $\begin{array}{l}\text { Chest } \\
\text { pass }\end{array}$ & $\begin{array}{c}\text { shoulder } \\
\text { pass }\end{array}$ & $\begin{array}{l}\text { Set } \\
\text { shot }\end{array}$ & $\begin{array}{l}\text { Lay- } \\
\text { up- } \\
\text { shot }\end{array}$ & $\begin{array}{l}\text { defensive } \\
\text { footwork }\end{array}$ \\
\hline \multirow{2}{*}{3} & \multirow{2}{*}{$\begin{array}{c}\text { External } \\
\text { Awareness }\end{array}$} & Right & $0.82 *$ & $0.92 *$ & $0.91 *$ & $0.62 *$ & $0.87 *$ & $0.91 *$ \\
\hline & & Left & $0.85 *$ & $0.93 *$ & $0.93 *$ & $0.56 *$ & $0.90 *$ & $0.96 *$ \\
\hline 4 & \multicolumn{2}{|c|}{ Optical tracking test } & $0.84 *$ & $0.93 *$ & $0.92 *$ & $0.58 *$ & $0.89 *$ & $0.93 *$ \\
\hline \multirow{5}{*}{5} & \multirow{5}{*}{$\begin{array}{l}\text { Test depth } \\
\text { perception }\end{array}$} & 10 & 0.11 & 0.04 & 0.04 & 0.04 & 0.07 & 0.01 \\
\hline & & 15 & 0.20 & 0.09 & 0.15 & 0.001 & 0.07 & 0.09 \\
\hline & & 20 & 0.20 & 0.22 & 0.21 & 0.03 & 0.22 & 0.18 \\
\hline & & 25 & 0.11 & 0.15 & 0.19 & 0.07 & 0.08 & 0.16 \\
\hline & & 30 & 0.11 & 0.09 & 0.13 & 0.07 & 0.08 & 0.14 \\
\hline
\end{tabular}

The value $(\mathrm{t})$ of the tabular at $(0.05)=0.361$

Clear from the results table (5) There is a statistically significant relationship between capacity Visual And performance Skills methodology Of the group Experimental at a ball The basket For pupils the ring the second From Education Basic Constraint Search as follows:

- There is a statistically significant relationship between speed Reply verb Visual and all the skills in question except where the value ranged between $t(0.19$ : $0.98)$

- There is a statistically significant correlation between the precision optical animation 6 touches the left and all the skills in question ranged value) (T) ( Between (0.19: 0.98)

- There is a statistically significant relationship between consciousness The outer right has all the skills under consideration as the value ranged ) (T) ( Between (0.07: 0.92)

- There is a statistically significant relationship between consciousness The exterior left has all the skills in question as the value ranged ) (T) ( Between (0.16: 0.96)

- There is a statistically significant relationship 
between the test Tracking Optics and all the skills under consideration where the value ranged ) $(\mathrm{T})$ ( Between (0.18: 0.93)

- No relationship is statistically significant between depth perception tests and all skill tests, where the value ranged between $t$ (0.001: 0.25)

It is clear From Schedule (24) There Relationship Associative At level moral (0.05) between Variables Visual Skills Basic (under Search) for the group Experimental The Hit Larger Valuable (T) (0.98) represent Relationship between Reaction speed and pass Chest at when Hit Less Valuable (T) (0.001) represent Relationship between Depth perception And corrigendum peaceful.

And confirms that What Reach mechanism All From, Jihan Fouad And Faith Abdullah (2005) (3), Nermin Fikri (2009) (7) at Importance Download Programs Training Visual at Development Capacity Visual I have Players Mathematics Individual The collective, and also "Abrens
Wood Abernethy and Wood (2002) (9), and the similarity of these study with the results of hypothesis "Hatem Fathallah Mohammed Alhven results of Me" (2011) (4) The researcher concluded that the proposed program of visual exercises proved positive effectiveness in the accuracy and speed of the offensive and defensive skills Epee performance and this is what Aukd health results of the study, and these are similar to the results of the study of the results of hypothesis "Amal Anwar Abdel - Salam" (2009) (2) The study aimed to: The researcher found that the educational program of visual qualitative affects visual skills and also affects the basic skills in table tennis, and this consistent with the results of the study hypothesis " Elizabeth Brion Elizabeth S3.Bresson "(2003) (11) The researcher found an improvement in passing the ball on the grid for the three groups of accuracy and showed the percentage of improvement that a dynamic program group Assiut Journal For Sport Science Arts 
T. vision showed greater improvement

And so Check my hypothesis the third And it is: "There are Relationship Statistically significant differences between the visual capabilities and the level of methodological skills for the experimental group 's performance in basketball.

Conclusions

and

\section{recommendations:}

First: Conclusions:

In the research sample and its potential and limits Frodah According to indicated by the results of statistical analysis could be reached the following conclusions:

1-Visual capabilities under Have a positive impact on the methodology following the basic skills level of performance (pass bra - Pass epaulettes - Interviewing Correction of stability - a peaceful break is illegal defensive moves ).

2-There is a correlation between some visual capabilities and basic skills methodology for basketball students the second cycle of basic education.

\section{Recommendations:}

In light of the research and conclusions based on the data and the findings of the researcher it recommended decision makers to put them in front of their eyes When formulating educational programs and curricula , namely:

1-Application tutorial using visual capabilities in teaching basketball second grade preparatory course for students in the second cycle of basic education because of its positive impact in upgrading the performance of methodological skills.

2- Interest in measuring the visual capabilities in the journal (depth perception visual reaction speed - external awareness - optical tracking precision optical animation) to find out the students in the visual capacity performance level in order to raise the level of students in the performance of basketball faster and better. 
1- $\quad$ Tamim Ahmed Adel

(2013): The effect of an educational program using visual skills at the level of basic skills for the field hockey performance, master, holistic of Physical Education, Assiut University.

2- $\quad$ Amal Anwar Abdel Salam (2009): The effect of an educational program on some qualitative Bosra basic skills in table tennis, Published research, Assiut Journal of Arts and Sciences of Physical Education.

3- Jihan Mohamed Fouad, Iman Abdullah Zaid (2005): visual training on the effectiveness of some skill variables and visual abilities in volleyball, research publication, Comprehensive Education Research Journal, Vol . II, No. II, Faculty of Physical Education for Girls, Zagazig University.

4- Hatem Fathallah Mohamed Hefny (2011): The effect of a training program using visual exercises on the accuracy and speed performance of some offensive and defensive skills in the sport of fencing, Ph.D. thesis is unpublished, Faculty of Physical Education, Assiut University.

\section{5- Majid Mustafa Ahmed} Ismail, Abdul Mohsen Zakaria Ahmed (2006): The impact of vision exercises some visual capabilities and the level of skill performance in football, research publication, Assiut Journal of Arts and Sciences of Physical Education, , Part IV.

\section{6- Mei Mohsen Abu Nour} (2013): relationship vision and visual perception variables sense - kinesthetic results in sport fencing men, Master Thesis, Faculty of Physical Education, Minia University.

\section{7- Nermin Fikri Alglma} (2009) : the effectiveness of the program of visual vision on some visual capabilities and skills of cognitive and visual level performance skills in basketball, Journal of Science and Arts Sports, Vol . (32), second edition, Faculty of Physical Education Girls, Helwan University. 
8- And Wood Abernethy (2004): Do. Generalized visual training programs for. Sports really work? An experimental investigation. J of Sports Sc.

9. Abernethy, Joanne M of Wood (2004): Do the Visual Tralining Programmers For Sport Ceneralized Really workTel? An Experimental, Journal of Sport Sciences , 19,203-222.

10- The Arial : Brain (2004): Sports Vision Training An Expert, Book To Improving Performance Training by vBulletin ${ }^{\circledR}$ The eyes View , Human Perception And Human Performance.

11. S Bressa elizabeth (2003): Effects of visual Skills Training Of Vision Coaching And Sport On The Vision dynamics, Performance Of
Sport Skill, African Journal Unit For Physical, Health Education, Recreation And Dance, Vol.9, No., 1.

12- Isabel has Weaker (2001): Why of visual Training Programmes For Sport Do Not workTel, Sports the Sci, Join Date : Mar 19 (3) P203-22.

13- Jim Brown (2001): Sports Talent (How To Identify And Develop Outstanding Athletes), Human Kinetics, usa 14-, Thomas A. The Wilson, by Jeff (2004): Sport Vision Training For the Better Performance, Kinetics Human Body Feb.Vision On Sway During Different Bostyrs In Elite Gymnasts, an int J Sport., Mar, 26 (2): 116-9, 2. 15- Http // Www.iraqacad.org / Hile / Amro.htm . 